\title{
SEMANGAT KEWIRAUSAHAAN \\ DALAM ETIKA PROTESTAN DAN MANAJEMEN \\ QOLBU: SEBUAH PERBANDINGAN
}

Sulaiman Al-Kumayi*

\section{Abstract}

This paper will highlight the spirit of enterpreneurship in perspective of the Protestant Ethics (PE) and the Manajemen Qolbu (MQ) founded by K. H. Abdullah Gymnastiar, known as Aa Gym. Both are represenstative for Christian and Islam, respectively. PE— a thesis proposed by Max Weber-assumed a close correlation between the spirit of Protestantinism and the emerge of capitalism in Europe. Refering to this Weber's thesis, I will examine the MQ in terms of its relation to the emerge of enterpreneurship among moslems in the Pondok Pesantren Daarut Taubiid, Bandung, West Java. MQ is an icon and identically addressed to Aa Gym. He is known as an enterpreneur-preacher (dai-pebisnis) which is proved with his success in developing some bussines like MQTV, MQ Jernih, Al-Qur'an Selular, etc.

This article is trying to explore further, some similarities and diversities between PE and MQ. And based on my research, the spirit of enterpreneurship established by $A a$ Gym has resemblance with the Protestant Ethics.

Keywords: Semangat Kewirausahaan, Etika Protestan, Manajemen Qalbu, Ekonomi, Bisnis.

TESIS Max Weber ${ }^{1}$ yang sangat terkenal "Etika Protestan" (The Protestant Ethics, die Protestantische Ethik) dan hubungannya dengan

*Penulis adalah dosen Fak. Ushuluddin IAIN Walisongo Semarang, Jln. Walisongo 3-4 Semarang 50151. e-mail: kecerdasan99_1973@yahoo.com. 
"Semangat Kapitalisme" (The Spirit of Capitalism) ${ }^{2}$ yang dilansirnya pada tahun 1905 telah menimbulkan sejumlah perdebatan di kalangan intelektual; ada yang pro dan ada yang kontra dengan tesis tersebut. Diduga kuat, Weber merupakan satu-satunya sosiolog yang berani berteori tentang adanya korelasi antara semangat kapitalisme modern di dunia Barat dan Etika Protestan. Menurutnya, agama-khususnya agama Protestan-merupakan faktor yang determinan, berdiri sendiri, dan berpengaruh terhadap semangat kapitalisme. Ini bertolak belakang dengan Karl Marx yang menempatkan agama pada posisi sekunder dan dependen. ${ }^{3}$

Temuan Weber tersebut bermula dari penelitiannya yang sangat intens di perusahaan-perusahaan Eropa. Ia menunjukkan bahwa para pemimpin perusahaan dan pemilik modal, maupun

${ }^{1}$ Max Weber-selanjutnya disebut Weber-dilahirkan 21 April 1864 di Erfurt dan meninggal 14 Juni 1920 di Munich Jerman, karena peradangan paru-paru. Ia dibesarkan di Berlin, kemudian melanjutkan pelajarannya di Universitas Heidelberg, Strassburg, Berlin, dan Gottingen dengan perhatian khusus pada bidang hukum, sejarah, dan teologi. Tahun 1889 memperoleh gelar Doktor di Berlin. Setelah mengajar dan mulai melakukan penelitianpenelitian, pada 1893 diangkat sebagai Guru Besar Hukum di Berlin. Tahun 1893-1897 menjalani praktik hukum di Berlin. Pada tahun ini pula ia diangkat sebagai Guru Besar Hukum Dagang di Berlin. Tahun 1894 diangkat sebagai Guru Besar dalam bidang Ekonomi Politik di Universitas Freiburg. Tahun 1905 dia menerbitkan esainya yang kemudian mengangkat namanya menjadi populer dan terkenal, "The Protestant Ethic and the Spirit of Capitalism" (Die Protestantische Ethik und der Geist de Kapitalismus). Setelah itu, ia pun menjadi aktivis di bidang politik dan kenegaraan. Lihat Ajat Sudrajat, Etika Protestan dan Kapitalisme Barat: Relevansinya dengan Islam Indonesia (Jakarta: Bumi Aksana, 1994), 1.

${ }^{2}$ Buku berbahasa Jerman ini terbit pada tahun 1905 di Jerman. Sosiolog Talcott Parson menerjemahkannya ke dalam bahasa Inggris menjadi The Protestant Ethic and the Spirit of Capitalism (New York: Charles Scribner's Son, 1958).

${ }^{3}$ Bryan S. Turner, Sosiologi Islam: Suatu Tinjanan Analitis atas Tesa Sosiologi Weber, ter. G. A. Tocialu (Jakarta: Rajawali Press, 1984), 7. 
mereka yang tergolong sebagai buruh terampil dan ahli tingkat tinggi, terlebih lagi karyawan-karyawan perusahaan modern yang sangat terlatih dalam bidang teknis dan niaga, sebagian besar beragama Protestan. ${ }^{4}$ Menurut Anthony Giddens, temuan Weber bukan hanya merupakan fakta kontemporer, melainkan merupakan suatu fakta sejarah. Jika ditelusuri ke belakang, beberapa pusat awal dari perkembangan kapitalis awal abad XVI M merupakan pusat yang sangat kuat unsur Protestannya. ${ }^{5}$

Sebenarnya pandangan Weber ini tidaklah benar-benar baru. Pendahulunya, seperti Warner Sombart, telah pula mengajukan teori yang sama. Menurut Sombart, sistem-sistem dan gereja memang dapat memberikan pengaruh terhadap perilaku ekonomi melalui cara-cara yang berbeda. Kekuatan sistem tersebut akan mengarahkan pikiran (mind) kepada tercapainya tujuan tersebut. Pengaruh-pengaruh tersebut, baik langsung maupun tidak, akan memberikan kecenderungan rangsangan dan dorongan-dorongan tertentu. Kenyataannya ini sesungguhnya berkorelasi erat dengan sejarah gereja dan sistem-sistem keagamaan. ${ }^{6}$ Atas dasar itu, dapat dikatakan bahwa semangat kapitalisme modern secara khas ditandai oleh suatu kombinasi unik kegairahan kepada usaha untuk memperoleh kekayaan dengan melakukan kegiatan ekonomi di satu pihak, disertai ketaatan tertentu yang berakar pada suatu agama/kepercayaan di pihak lain. ${ }^{7}$

Tesis Weber kemudian diperkuat oleh temuan penelitian Bellah yang menyatakan bahwa kemajuan ekonomi bangsa

${ }^{4}$ Max Weber, The Protestant Ethic and the Spirit of Capitalism (New York: Charles Scribner's Son, 1958), 35.

5Anthony Giddens, Kapitalisme dan Teori Sosial Modern: Suatu Analisis Karya Tulis Marx, Durkheim, dan Max Weber, ter. Suheba Kamadibrata (Jakarta: UI Press, 1985), 153.

${ }^{6}$ Robert W. Green (ed.), Protestantism and Capitalism: The Weber Thesis and It's Critics (Boston: D. C. Heath and Company, 1959), 29.

${ }^{7}$ Sudrajat, Etika ..., 5. 
Jepang berkaitan erat dengan Sintoisme. ${ }^{8}$ Dalam konteks kebangkitan ekonomi Cina, mungkinkah bisa dikatakan berakar dari Konfusianisme?

Berpijak dari tesis Weber di atas, tulisan ini selanjutnya akan mencoba menerapkan tesis tersebut terhadap Islam dan pertanyaan mendasar yang diajukan adalah apakah ajaran Islam mempunyai unsur-unsur yang mendorong the spirit of enterpreneurship?? Untuk maksud tersebut, penulis memilih Pondok Pesantren Daarut Tauhiid Bandung dengan ikon Manajemen Qolbu-nya (selanjutnya disingkat MQ) sebagai kasus utama. Alasan utama pemilihan pondok pesantren yang diasuh oleh Abdullah Gymnastiar-akrab disapa Aa Gym-ini adalah fakta bahwa Aa Gym, menurut Hermawan Kartajaya, merupakan a spiritual marketer yang ia menjadikan ajaran Islam sebagai motivasi utama dalam menumbuhkan kewirausahaan. ${ }^{10}$ Menurut penilaian Hermawan Kartajaya, Aa Gym telah berhasil tampil sebagai pebisnis yang sangat sukses. Beberapa perusahaan yang didirikannya telah berkembang secara spektakuler. Ia mencontohkan MQTV (anak perusahaan MQ Corporation di bidang production house), sebagai rumah animasi sekaligus televisi penyiaran. Hanya dengan modal awal Rp 3.000.000.000 (tiga miliar), MQTV telah mampu memberikan warna bagi dunia pertelevisian di Tanah Air. ${ }^{11}$ Tidak hanya itu, Aa Gym telah pula berhasil dalam menjalankan bisnisnya di bidang air minum,

${ }^{8}$ Robert N. Bellah, Tokugawa Religion: The Values of Pre-Industrial Japan (USA: Macmillan Publisher Company, 1984).

${ }^{9}$ Dalam tulisan ini saya mengubah terma the spirit of capitalism dengan the spirit of enterpreneurship. Perubahan terma ini tentunya memang mengandung konsekuensi, tetapi istilah the spirit of enterpreneurship barangkali terdengar lebih netral dan bermakna positif dibanding istilah yang pertama. Namun, pertimbangan yang paling penting adalah fakta bahwa term the spirit of enterpreneurship lebih cocok untuk Manajemen Qolbu (MQ).

${ }^{10}$ Hermawan Kartajaya, Aa Gym: A Spiritual Marketer (Bandung: MarkPlus \& Co-MQS Publishing, 2005).

${ }^{11}$ Ibid., 29. 
swalayan, perhotelan, travel, dan lain-lain. Tentu saja semua ini cukup mencengangkan karena landasan utama bisnis Aa Gym adalah ajaran Islam.

Untuk memahami lebih jauh fenomena di atas, tulisan ini akan mencoba memahami kewirausahaan yang dikembangkan Pondok Pesantren Daarut Tauhiid dalam perspektif teori sosiologi agama yang dikembangkan oleh Max Weber. Selanjutnya, penulis membatasi hanya pada sekte Calvinis yang banyak disorot Weber, kemudian membandingkannya dengan MQ (Manajemen Qolbu).

\section{Pengaruh Pilihan Teologis}

Memang agak berlebihan menghubungkan pilihan teologis dan semangat kewirausahaan meskipun sebenarnya keduanya mempunyai korelasi yang tidak bisa diabaikan begitu saja. Yang jelas, kewirausahaan menentukan kemajuan dan perkembangan suatu bangsa. Jika rakyatnya lemah dalam wirausaha, maka dapat dipastikan bangsa itu akan menjadi bangsa terbelakang.

Para ahli, semisal Rostow, menekankan bahwa perilaku kewirausahaan sangat menentukan kemajuan dan perkembangan suatu bangsa. ${ }^{12}$ Sumanhadimidjaya, sebagaimana dikutip Nanat Fatih Natsir, mengemukakan bahwa bila suatu negara ingin maju dalam bidang perekonomian, maka negara tersebut membutuhkan $2 \%$ penduduknya berjiwa wirausaha yang unggul dan $20 \%$ berjiwa wirausaha sedang. ${ }^{13}$

Untuk mengukur tingkat kewirausahaan suatu masyarakat, Yuan dan Low dari The Institute of Policy Studies Singapura, mengemukakan bahwa tingkat kewirausahaan dapat diukur dengan membandingkan jumlah perusahaan yang ada di suatu

${ }^{12}$ Lihat W. Walter Rostow, "The Take of Self-Sustained Growth" dalam Agrawala dan Singh (ed.), The Economic of Under Development (New York: Oxford University Press, 1958), 154-88.

${ }^{13 N a n a t}$ Fatah Natsir, Etos Kerja Wirausahawan Muslim (Bandung: Gunung Djati Press, 1999), 1. 
masyarakat terhadap jumlah perseribu penduduk. ${ }^{14}$ Sebagai gambaran sementara, Badan Pusat Statistik (BPS) tahun 1991 menyebutkan ada enam belas unit badan usaha tiap seribu penduduk di Indonesia untuk tahun 1990. Angka ini sudah termasuk yang tidak berbadan hukum, seperti sektor informal yang bergerak dalam perdagangan eceran dan warteg-warung tegal. Pada tahun yang sama Hongkong menunjukkan angka 29 perusahaan, Korea Selatan 36 perusahaan, Singapura 35 perusahaan, Taiwan 27 perusahaan, India 14 perusahaan, Pakistan 13 perusahaan, Malaysia 19 perusahaan, Philipina 18 perusahaan, dan Thailand 21 perusahaan. Melalui data tersebut, terbaca dengan jelas bahwa kualitas kewirausahaan bangsa Indonesia berada di bawah negara ASEAN lainnya.

Sebagai bangsa yang mayoritas beragama Islam, data di atas setidak-tidaknya cukup menghenyak karena secara tidak langsung umat Islam bertanggung jawab terhadap rendahnya minat kewirausahaan bangsa Indonesia. Dengan kata lain, carutmarutnya perekonomian bangsa ini adalah konsekuensi logis dari rendahnya the spirit of enterpreneurship umat Islam. Benarkah?

Para ahli berpandangan bahwa tinggi rendahnya tingkah laku kewirausahaan suatu bangsa berkaitan erat dengan kualitas sumber daya manusia. Kualitas sumber daya manusia dipandang berkaitan dengan berbagai faktor, yang salah satu faktor utama adalah agama. Menurut Lester Kurtz, agama menyediakan prinsip-prinsip besar untuk menjelaskan dunia dan kehidupan etis bagi masyarakat. ${ }^{15}$ Dengan demikian, etos kewirausahaan itu sesungguhnya telah ada dalam agama itu sendiri. Akan tetapi, faktanya bangsa-bangsa muslim mengalami keterbelakangan luar biasa. Adapun penyebab utamanya, menurut Weber, karena Islam bersemangat hedonis murni, yang mengutamakan kesenangan dan kebahagiaan dalam hidup, khususnya terhadap

${ }^{14}$ Ibid.

15Lester Kurtz, Gods in the Global Village: The World's Religions in Sociological Perspective (London: Pine Forge Press, 1995), 3. 
wanita, kemewahan, dan harta benda. Mengingat kemudahan yang diberikan oleh Etika Qur'an, tidak terdapat pertentangan antara perintah-perintah moral duniawi dan hasilnya. Hal ini berarti bahwa tidak mungkin etika asketis yang dominan akan muncul dari dunia Islam. ${ }^{16}$

Pernyataan Weber di atas, menurut Turner, sangat mudah ditafsirkan. Dikarenakan asketisme tidak ada dalam Islam, dapat dijelaskan sebab musabab kapitalisme rasional tidak dapat pula tumbuh di dalam masyarakat yang didominasi oleh budaya Islam. ${ }^{17}$ Dalam hal ini, tampak jelas pembacaan Weber terhadap Islam berdasarkan pada pembacaannya terhadap Etika Protestan sehingga segala sesuatunya ia ukur dalam "cermin" tersebut.

Dengan nada yang agak sinis, Louis_-seperti yang dikutip Natsir-mengemukakan bahwa umat Islam mempunyai etika kerja yang cacat sehingga membuat mereka ketinggalan dari penganut agama besar lainnya. Karena sumber ajaran mereka bersumber pada al-Qur'an, maka tidak heran kalau ada yang berpendapat bahwa kelemahan etika kerja mereka bersumber dari al-Qur'an. ${ }^{18}$

Para pemikir muslim, seperti direpresentasikan oleh Harun Nasution, menolak anggapan bahwa al-Qur'an bertanggung jawab terhadap lemahnya etos kerja umat Islam. Menurutnya, lemahnya etos kerja itu lebih disebabkan oleh kekeliruan pemahaman umat Islam terhadap al-Qur'an. Apalagi kesalahpahaman itu kemudian melahirkan berbagai aliran teologi dalam Islam sehingga secara tidak langsung berpengaruh terhadap etos kerja. ${ }^{19}$ Cendekiawan muslim lainnya, seperti M. Quraish Shihab, juga menolak tudingan miring ini. Menurutnya,

${ }^{16 B r y a n}$ S. Turner, Sosiologi Islam: Suatu Telaah Analisis atas Tesa Sosiologi Weber (Jakarta: Rajawali Press, 1991), 13.

${ }^{17}$ Ibid.

${ }^{18}$ Natsir, Etos ..., 4.

${ }^{19}$ Lihat lebih jauh Harun Nasution, Teologi Islam: Aliran-aliran, Sejarah Analisa Perbandingan (Jakarta: UI Press, 1986). 
al-Qur'an mendorong manusia untuk bekerja dan berbisnis, bahkan kitab suci ini telah menyediakan seperangkat aturan dalam berbisnis. ${ }^{20}$ Dalam hal kerja keras, tandas Shihab, alQur'an tidak memberi peluang bagi seorang muslim untuk menganggur sepanjang saat yang dialami dalam kehidupan dunia ini. Dalam hidup di dunia ini, prinsip dasar yang ditekankan alQur'an adalah kerja keras. "Tidak ada yang akan diperoleh manusia kecuali hasil usahanya sendiri" (Qs. al-Najm [53]: 39). ${ }^{21}$

Dalam ranah realitas, tampaknya kita harus mengakui adanya korelasi antara pilihan teologis dan etos kerja. Penelitian Nanat Fatah Natsir membuktikan eratnya kaitan ini. Natsir melakukan penelitian di Tasikmalaya, Jawa Barat (1999) dengan sampel pimpinan dan buruh perusahaan muslim. Dari hasil penelitiannya itu, Natsir menemukan bahwa pilihan teologi mempengaruhi etos kerja. Yang cukup menarik, para pimpinan perusahaan cenderung menganut faham Qadariyyah, dan para buruh cenderung menganut Jabariyyah.

Bagi orang Islam yang cenderung mengapresiasi pemikiran Qadariyyah, memiliki pemahaman tentang ikhtiyâr secara lebih positif, yaitu bahwa keberhasilan dalam kegiatan ekonomi sangat ditentukan oleh sejauh mana upaya-upaya yang dilakukan oleh manusia itu sendiri untuk meraih keberhasilan atau keuntungan dalam usahanya, bukan semata-mata ditentukan oleh Allah swt. Karena itu, kerja keras, hemat, jujur, dan bertanggung jawab dalam usaha, merupakan bagian dari ikhtiyâr manusia sebagai prasyarat untuk meraih keberhasilan atau keuntungan dalam usaha mereka. Sedangkan bagi yang berpaham Jabbariyyah, pemahaman mereka tentang ikhtiyâr cenderung fatalis-

${ }^{20}$ Lihat M. Quraish Shihab, "Etika Bisnis Dalam Wawasan al-Qur'an” dalam Jurnal Kebudayaan dan Peradaban Ulumul Qur'an, No. 3, Vol. VII/1997, 4-9; M. Quraish Shihab, Tafsir Al-Qur'an Al-Karim: Tafsir atas Surat-surat Pendek Berdasarkan Urutan Turunnya Wabyu (Bandung: Pustaka Hidayah, 1418/1997), 462-3.

${ }^{21}$ Ibid., 6. 
deterministik, bahwa keberhasilan usaha manusia-termasuk keberhasilan dalam kegiatan ekonomi-sangat ditentukan oleh kehendak Allah swt. semata-mata, bukan ditentukan oleh adanya kerja keras, hemat, jujur, dan berperhitungan dalam kegiatan usaha. $^{22}$

Ditambahkan Natsir, perbedaan pilihan teologis berpengaruh dalam memahami term ibadat. Bagi yang menganut Qadariyyah, ibadat mencakup semua aspek, termasuk usaha dalam kegiatan ekonomi. Karena itu, kerja keras, hemat, rajin, jujur, dan berperhitungan dalam kegiatan ekonomi merupakan keharusan menurut ajaran Islam sebagai panggilan suci yang memiliki makna ibadat kepada Allah, yang menurut istilah Weber, disebut asketisme duniawi. Hal tersebut bermakna menjadikan kegiatan di dunia sebagai bagian dari ibadat serta keselamatan dicari dengan mengalahkan dunia. ${ }^{23}$

Di lain pihak, mereka yang menganut Jabbariyyah memiliki pemahaman tentang ibadat yang cenderung lebih menekankan pada kegiatan keagamaan yang bersifat ritual, yaitu hubungan manusia dengan Allah memiliki makna keakhiratan ('ibâdah mạdlah), seperti salat dan puasa. Sedangkan kegiatan usaha dalam bidang ekonomi, misalnya kerja keras, hemat, berperhitungan, rajin, dan jujur, dipahami kurang memiliki makna ibadat untuk kepentingan akhirat dan cenderung diabaikan. Karena itu, mencari rezeki untuk mendapatkan keuntungan yang terus-menerus hingga menjadi orang kaya tidak terlalu menjadi cita-cita mereka, bahkan mereka meyakini bahwa nasib manusia segalanya telah ditentukan oleh Allah sejak zaman azali, baik akan menjadi orang kaya atau miskin yang menurut istilah Weber asketisisme bukan duniawi, yaitu mencari keselamatan pada kemampuan mengalahkan segala keinginan dunia bagi kepentingan ibadat. ${ }^{24}$

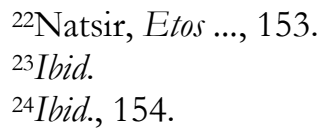

${ }^{23}$ Ibid.

${ }^{24}$ Ibid., 154. 
Temuan Natsir di atas, tampaknya perlu dipertanyakan jika kita mengkaji semangat kewirausahaan yang dikembangkan di Pondok Pesantren Daarut Tauhiid Bandung yang dipimpin oleh Abdullah Gymnastiar. Sepanjang penelitian yang saya lakukan, ${ }^{25}$ Daarut Tauhiid tidak mau terjebak dalam perdebatan fikih dan teologis. Slogan yang ditampilkan di lembaga pendidikan Islam tersebut adalah "mazhab silaturrahmi." Dalam sebuah pernyataannya di Majalah Tempo edisi 3 April 1993, Aa Gym mengatakan, "Saya belajar pada setiap orang, dan mazhab saya mazhab silaturrahmi." Dengan pernyataannya ini, akan menjadi sia-sia seandainya ada sebagian ahli atau kelompok tertentu yang mencoba mengidentifikasi "mazhab" Aa Gym dan Pondok Pesantren Daarut Tauhiid.

Di tempat lain, kita akan temukan maksud "mazhab silaturrahmi” yang dipegang oleh Aa Gym di atas:

"Nabi Muhammad saw. yang sempurna segala-galanya tetap saja ada yang membenci, menghina, dan memusuhi. Apalagi saya yang baru taubat dan belajar agama kemarin sore. Bagi saya, sehebat apa pun upaya kebaikan yang kita lakukan pasti tak akan seratus persen orang yang senang. Sudah sunnatullah, selalu akan ada saja yang tak suka, bahkan akan ada pula orang-orang yang berupaya menghalangi. Untuk itu, kita harus jadikan kaum oposisi itu sebagai sarana evaluasi diri. Kita harus jernih hati dalam menghimpun info yang akurat untuk ditafakuri. Siapa tahu hal itu merupakan karunia Allah untuk memperbaiki kekurangan yang tak sadar kita lakukan. Di samping itu, kita pun bisa menjadikan kritik, koreksi, dan penghinaan menjadi sarana berlatih kesabaran, berlatih berlapang dada, berlatih tak mudah tersinggung, berlatih agar tak membenci sehingga kita terlatih untuk tetap

25Saya telah menulis dua buku tentang Aa Gym: [1] Kearifan Spiritual: Dari Hamka ke Aa Gym (Semarang: Pustaka Rizki Putra, 2004), yang mengalami dua kali cetak dalam setahun; [2] Menuju Hidup Sukses: Kontribusi Spiritual-Intelektual Aa Gym dan Arifin Ilham (Semarang: Pustaka Rizki Putra, 2005). Buku ini dalam setahun mengalami dua kali cetak ulang dan akan dicetak ulang lagi. Berbeda dengan buku-buku yang sejenis, dua buku ini ditulis dengan riset ilmiah dan bukan didorong oleh kepentingan "market" semata-mata. 
menyayangi. Bukankah petinju yang tangguh selalu butuh sparing partner?

Dan yang sangat penting lagi adalah kita harus menjadikan orang yang tak menyukai kita sebagai ladang amal. Balaslah keburukan dengan kebaikan, bersilaturahmi, dan tetap memberikan dukungan agar bisa lebih sukses". 26

Dengan demikian, kewirausahaan yang dikembangkan oleh Aa Gym dan pesantrennya sama sekali tidak ditentukan oleh pilihan teologis, tetapi benar-benar didorong oleh al-Qur'an dan sunnah. Dalam beberapa kesempatan, Aa Gym selalu menegaskan bahwa bisnis yang dilakukannya semata-mata mengikuti cara-cara bisnis Rasulullah. Rasulullah, tandas Aa Gym, telah mempraktikkan cara berbisnis yang Islami-orientasinya bukan semata-mata mencari keuntungan tetapi ibadat kepada Allah dan kemandirian—sehingga Rasulullah tampil sebagai seorang pengusaha muda yang sukses. ${ }^{27}$

Di sinilah sesungguhnya fenomena yang sangat menarik untuk didiskusikan lebih lanjut. Penulis menganggap perlu untuk "membandingkan" the spirit of enterpreneuship Manajemen Qolbu (MQ) dengan Etika Protestan (EP). Karena adanya keterbatasan wilayah kajian, penulis hanya mengambil sekte Calvinisme sebagai sample dalam tulisan ini. Max Weber sendiri sangat menaruh perhatian khusus terhadap "sekte" ini.

\section{Calvinis dan MQ}

Berikut akan dipaparkan beberapa prinsip dasar yang dipegangi oleh EP dan MQ dalam mengembangkan the spirit of enterpreneurship.

26Sulaiman Al-Kumayi, Kearifan Spiritual: Dari Hamka ke Aa Gym (Semarang: Pustaka Rizki Putra, 2004), 82. Sumber asli buku ini adalah tulisan Abdullah Gymnastiar, Aa Gym Apa Adanya: Sebuah Qolbugrafi (Bandung: MQ Publishing, 1424/2002), 152.

${ }^{27}$ Abdullah Gymnastiar, "Berbinis dari Kedalaman Hati" dalam Hermawan Kartajaya, Aa Gym: A Spiritual Marketer (Bandung: MarkPlus \& Co-MQS Publishing, 2005), 247. 


\section{Asketisme Duniawi}

Protestan memberikan nilai positif terhadap dunia materiil yang bersifat kodrati. Agama ini menganggap materi sebagai sarana untuk melakukan usaha-usaha yang aktif. Sikap ini diambil karena memang demikianlah Tuhan menitahkan. Santo Paulus, misalnya, pernah menyatakan, "Mereka yang tidak bekerja tidak berhak mendapatkan makan." Ketidakmauan untuk bekerja merupakan gejala berkurangnya kemungkinan untuk memperoleh rahmat. ${ }^{28}$

Pandangan ini berbeda dengan pandangan Abad Pertengahan, seperti dapat kita baca dari tulisan Thomas Aquinas, yang memberikan interpretasi terhadap pernyataan Santo Paulus di atas. Bagi Aquinas, kerja hanya merupakan naturali ratione yang perlu dilakukan untuk memelihara setiap individu dan masyarakat. Ketika tujuan ini telah dicapai, ajaran atau perintah itu berhenti untuk mempunyai makna apa saja. Lebih jauh lagi, hal itu hanya berlaku untuk satu suku, bukan untuk setiap individu. Hal itu tidak berlaku bagi seseorang yang dapat hidup tanpa bekerja oleh karena harta kepemilikannya, dan tentu saja kontemplasi, sebagai bentuk perilaku spiritual di dalam kerajaan Surga, lebih diutamakan jika dibandingkan dengan firman itu di dalam pengertian literalnya. Seperti dicatat Weber, bagi teologi populer pada waktu itu, bentuk tertinggi dari produktivitas monastis terletak pada peningkatan dari Thesaurus melalui doa dan lagu pujian. ${ }^{29}$

Salah satu prinsip dasar yang dianut oleh Calvinis adalah "orang terpilih", mendorongnya untuk mencari keselamatan diri sendiri. Prinsip ini kemudian mendorong para pengikut Calvinis untuk melakukan aktivitas duniawi secara intens dan menganggapnya sebagai anugerah Tuhan yang akan mengantarkannya kepada keselamatan. Bekerja keras untuk

${ }^{28}$ Weber, The Protestant ..., 105

${ }^{29} \mathrm{Ibid}$. 
mengumpulkan materi dan mendistribusikannya kepada orang lain merupakan perbuatan terpuji.

Dalam kasus yang sama, MQ juga menganjurkan pentingnya melakukan aktivitas duniawi. Meskipun demikian, ini barangkali yang membedakan dengan Calvinis, harta bukanlah jalan keselamatan, tetapi hanya "ladang" untuk beramal. Aa Gym sangat menggalakkan kesalehan sosial sebagai manifestasi dari kesalehan individual. Dalam beberapa ceramahnya, ia pernah mengatakan bahwa "orang yang paling hebat, paling kuat, dan paling dahsyat adalah orang yang bersedekah tetapi tetap mampu menguasai dirinya sehingga sedekah, yang dilakukannya bersih, tulus, dan ikhlas tanpa ada unsur pamer ataupun keinginan untuk diketahui orang lain". ${ }^{30}$

Orang yang telah bekerja keras dan memperoleh harta, diharapkan menjadikannya sebagai sarana untuk beramal dengan cara mendistribusikannya untuk menolong sesama. Dalam hal ini, Aa Gym merujuk sabda Rasulullah saw. yang menjelaskan bahwa Allah swt. lebih menyukai mukmin yang kuat. Kekuatan iman saja tidak cukup, tetapi harus didukung kekuatan fisik, ekonomi, intelektual, strategi, dan manajemen. Membangun kekuatan itu adalah bagian dari upaya menggapai cinta Allah. Membangun kekuatan ekonomi dan sistem adalah sebuah ibadah. Perekonomian yang kuat akan berimbas pada tingkat kesehatan yang lebih baik sehingga kemampuan bekerja menjadi bagus. Makin kuat ekonomi, makin besar kemampuan untuk mengakses ilmu lebih banyak sehingga umat tidak bodoh dan gampang dibodohi, tidak meminta-minta, dan dapat berbuat lebih banyak. ${ }^{31}$

\section{${ }^{30}$ Ibid., 122.}

${ }^{31}$ Hernowo dan M. Deden Ridwan (ed.), Aa Gym dan Fenomena Daarut Taubiid (Bandung: Mizan, 2002), 67. Di tempat lain, Aa Gym menegaskan bahwa kebahagiaan sejati terletak pada kesiapan berkorban untuk orang lain. Aa Gym pernah menegaskan hal ini: "Harusnya kita merasa nikmat ketika makanan yang kita kumpulkan setiap hari bisa dinikmati oleh banyak orang. Bahkan andai kita hanya kebagian sedikit atau separuh saja. Kita harus merasa nikmat kalau rumah yang 
Menurut Aa Gym, orang yang mengklaim dirinya muttaqîn harus dibuktikan dalam tataran aplikatif. Ia mampu menjadikan dirinya sebagai jalan manfaat bagi orang lain, laksana cahaya matahari yang menerangi bermiliar umat manusia di bumi, mengeringkan tubuh-tubuh yang basah, menghangatkan setiap yang kedinginan, memunculkan dengannya biji, buah, dan makanan. Itulah visi hidup rahmatan li al-'âlamîn. Hidup semacam ini menjadi cahaya kasih sayang bagi segenap penjuru alam. ${ }^{32}$

\section{Waktu: Panggilan Mulia Tuhan}

Dorongan dasar yang cukup menarik dari EP dan MQ adalah pemanfaatan waktu sebaik-baiknya dan menganggapnya sebagai anugerah terbesar Tuhan. Melalui anugerah waktu, idealnya dapat mendorong manusia untuk menggunakannya dalam hal-hal yang positif dan produktif. Dan ini merupakan salah satu ciri masyarakat modern. Konsekuensi logis dari hal ini adalah EP dan MQ mendorong pengikut masing-masing untuk menumbuhkan the spirit of enterpreneurship (semangat kewirausahaan). Calvinis maupun MQ sama-sama didorong oleh keinginan untuk mengabdi kepada Tuhan meskipun dengan term yang berbeda. Merujuk Weber, sekte Calvinis Protestan sangat menekankan bahwa segala aktivitas idealnya semata-mata untuk Tuhan. ${ }^{33}$ Seorang penulis Calvinisme terkemuka, Richard Baxter, terutama lewat karyanya yang tersohor dan berpengaruh di kalangan Protestan, Saints' Everlasting Rest dan Christian Directory, sangat menekankan keniscayaan melakukan

dengan susah payah kita bangun, menjadi penuh sesak oleh anak-anak yatim, janda atau siapa pun yang ingin berteduh di rumah kita. Kita harus merasa nikmat jika pakaian sederhana yang kita miliki dipakai bersujud oleh saudara-saudara kita yang tidak mempunyai baju". Ibid, 44-5.

${ }^{32}$ Ibid., 47.

33Weber menyebutkan ada empat sekte penting dalam agama Protestan: (1) Calvinisme, (2) Pietisme, (3) Metodisme, dan (4) Sekte-sekte Baptis. Lihat Weber, The Protestant ..., 51-102. 
sesuatu dari dan untuk Tuhan. Karena itu, hidup ini haruslah diisi dengan kegiatan-kegiatan yang produktif dan tidak boleh bersantai-santai atau bermalas-malasan.

Baxter dalam bukunya memberikan pernyataan tegas, "suatu pekerjaan harus dikerjakan dari Dia yang telah mengutusnya, sejauh itu adalah harinya." Bukan waktu santai dan kenikmatan, tetapi hanya aktivitas yang bisa meningkatkan kemuliaan Tuhan, menurut manifestasi yang pasti dari kehendak-Nya. Dalam Christian Directory Baxter menyatakan:

"Demikianlah bahwa Allah memelihara kita dan aktivitas kita; kerja adalah ujung moral serta alami dari kekuatan...Dengan cara demikianlah Allah bisa dilayani dan dihormati... Kesejahteraan umum atau kebaikan banyak orang harus dijunjung di atas kesejahteraan dan kebaikan diri kita sendiri". ${ }^{34}$

Dorongan "ilahiah" ini dijelaskan lebih jauh oleh Baxter, supaya manusia tidak berbuat tanpa makna dalam hidup. AlKitab, demikian ungkap Baxter, tegas-tegas menyatakan "Bertekunlah dalam panggilanmu" (Work hard in your calling). Pernyataan itu mendorong para pengikut Calvinis untuk memanfaatkan sedemikian rupa waktu, tidak boleh membuang-buangnya. Membuang-buang waktu merupakan dosa pertama dan secara prinsip dosa yang paling mematikan. Rentang waktu kehidupan manusia secara tidak pasti adalah pendek dan berharga untuk memastikan pilihan hidup seseorang. Karena itu, menurut Baxter, kehilangan waktu melalui sosialitas, pembicaraan tidak menentu, kemewahan, bahkan tidur terlalu banyak dari yang semestinya bagi kesehatan (6 jam dan yang paling banyak 8 jam) merupakan kesalahan-kesalahan moral absolut. ${ }^{35}$

${ }^{34}$ Ibid., 230. Teks aslinya: "It is for action that God maintaineth us and our activities; work is the moral as well as the natural end of power...It is action that God is most served and bonoured by... The public welfare or the good of the many is to be valued above our own".

${ }^{35}$ Ibid., 104. 
Di bagian lain, ditegaskan oleh Baxter, waktu itu sungguhsungguh sangat berguna sehingga jika satu jam terbuang percuma itu berarti telah hilang kesempatan untuk bekerja demi memuliakan Tuhan. ${ }^{36}$ Baxter mencela kontemplasi yang pasif yang tidak membawa manfaat karena ia hanya menghabiskan waktu dan pengeluaran saja. Di samping itu, pekerjaan ini sama sekali tidak membahagiakan Tuhan, sedangkan Tuhan menuntut kita untuk berkarya aktif dalam kehendak-Nya, dan inilah panggilan-Nya. ${ }^{37}$

Sementara itu, pendiri dan praktisi MQ, Abdullah Gymnastiar, berpendapat bahwa hal yang paling berharga bagi seorang muslim setelah iman adalah waktu. Waktu ini idealnya dimanfaatkan untuk hal-hal yang produktif dan tidak diperkenankan menghabiskannya "tanpa bekas" atau tanpa hasil konkret. Ditambahkan Aa Gym, waktu adalah amanah Allah yang akan dimintai pertanggungjawaban di akhirat. Untuk itu, setiap detik yang dilalui harus diperhitungkan dengan secermatcermatnya, sematang-matangnya, dan seakurat-akuratnya lalu mengisinya dengan hal-hal yang membuahkan peningkatan kemampuan kita. ${ }^{38}$ Ciri lain yang menonjol dari EP dan MQ adalah keharusan bekerja keras dalam hidup dan tidak diperkenankan bermalas-malasan. Karena itu, hendaknya

36Dalam Christian Directory (I: 383) disebutkan: "Jagalah nilai waktu yang tinggi dan lebih waspadalah setiap hari agar kamu tidak kehilangan waktumu, yang lebih penting daripada kewaspadaanmu agar kamu tidak kehilangan emas dan perakmu. Dan jika rekreasi, pakaian, pesta-pesta, pembicaraan kosong, pertemanan yang tidak menguntungkan, atau tidur yang semuanya sia-sia menjadi godaan yang akan merampas kamu dan waktumu, demikian pula tingkatkan kewaspadaanmu". Lihat Weber, The Protestant ..., 231.

${ }^{37}$ Hernowo, Aa Gym ..., 105.

${ }^{38}$ Ibid., 26. Lebih jauh Aa Gym menyatakan: "Sesungguhnya waktu adalah sesuatu yang paling berharga sehingga kita terkadang membiarkannya terhambur sia-sia, berjalan sia-sia, memboroskannya dengan sia-sia, dan lain-lain yang serba sia-sia. Kita sering membiarkannya berlalu begitu saja. Padahal, semestinya. Lihat Abdullah Gymnastiar, Demi Masa! Menggenggam Waktu, Meraih Keunggulan Diri (Bandung: MQ Publishing, 1425/2004), viii. 
mengisi waktu ini dengan perbuatan-perbuatan yang diridai oleh Allah, di antaranya adalah dengan bekerja keras. Bekerja itu setara dengan jihhâd fî sabîl al-Lâh. Ia mengutip hadis Nabi saw., "Sesungguhnya Allah suka kepada hamba yang berkarya dan terampil. Barangsiapa bersusah payah mencari nafkah untuk keluarganya, maka dia serupa dengan seorang mujâhid fî sabîl alLâh" (HR. Imam Ahmad). Hadis ini dijadikan rujukan utama oleh MQ sebagai dorongan bagi seorang muslim untuk meningkatkan keterampilan dan bekerja keras dalam mencari nafkah. Bahkan, kerja keras itu disetarakan dengan jihad dan pelakunya adalah seorang mujahid. ${ }^{39}$ Buah dari prinsip ini adalah akan tumbuh pribadi-pribadi muslim yang mandiri yang tidak mengantungkan diri kepada orang lain. Ia merujuk firman Allah: "Sesungguhnya Allah tidak mengubah keadaan suatu kaum, sehingga mereka mengubah keadaan yang ada pada diri mereka sendiri” (Qs. alRa`d [13]: 11). Firman Allah ini, menurut Aa Gym, menegaskan bahwa nasib seseorang bergantung pada dirinya sendiri sehingga secara eksplisit Allah menyuruh setiap orang untuk mandiri. Kemandirian inilah kunci sukses di dunia dan di akhirat. ${ }^{40}$

Dengan kata lain, Aa Gym menekankan betapa perubahan nasib itu sangat tergantung pada jiwa kemandirian, karena potensi ini sebenarnya sudah diberikan oleh Allah swt. kepada setiap individu. Ini dinyatakan secara eksplisit dalam tulisannya:

"Tugas kita adalah menggali dan mengembangkan diri kita dengan baik sehingga hidup yang sekali-kalinya ini tidak menjadi beban bagi orang lain, bahkan hidup terhormat karena bisa meringankan beban orang lain. Hal ini telah ditegaskan dalam sabda Rasulullah saw. bahwa sebaik-baik manusia adalah manusia yang paling banyak manfaatnya". ${ }^{41}$

${ }^{39}$ Abdullah Gymnastiar, Etika Bisnis MQ (Bandung: MQ Publishing, 2004), 11.

40Abdullah Gymnastiar, Malu Jadi Benalu (Bandung: MQ Publishing, 2004), 12.

${ }^{41}$ Ibid., 11. 
Di sini Aa Gym memahami makna jihad tidak lagi mengangkat senjata, tetapi lebih memandang pada titik lemah umat Islam itu sendiri. Menurutnya, titik terlemah umat adalah perekonomian. Aa Gym menekankan masalah ini dengan tulisannya berikut:

"Kalau kita berjuang dengan sungguh-sungguh untuk kemaslahatan umat di bidang ekonomi, maka insya Allah upaya seperti ini juga adalah jihad. Usaha kita untuk membangkitkan ekonomi umat, agar umat menjadi kokoh dan bermartabat, insya Allah itupun sebuah perjuangan". 42

Pemaknaan jihad seperti di atas berkaitan erat dengan kondisi perekonomian umat Islam yang terjajah. Persoalan bisnis tampaknya masih menjadi salah satu kelemahan umat Islam. Hal ini disebabkan oleh kurang tepatnya dalam mempersepsi bisnis.

"Dampaknya dapat dilihat dari kondisi umat saat ini, umat tidak punya apa-apa, perekonomiannya pun dijajah orang lain. Dan nampaknya inilah salah satu strategi musuh-musuh Islam, yaitu dengan memperlemah ekonomi umat. Sebabnya, tiada lain karena urusan bisnis dianggap urusan duniawi. Padahal bisnis menjadi urusan duniawi jikalau niat dan caranya salah, tetapi jika niat dan caranya benar maka bisnis adalah jihad". 43

\section{Catatan Akhir}

Uraian di atas, meski hanya sekilas, memberikan gambaran nyata, tentang sikap dan pandangan EP dan MQ dalam menyikapi kehidupan, yaitu the spirit of enterpreneurship yang ditandai oleh penghargaan terhadap waktu dan kerja keras benar-benar dilaksanakan. Keduanya sepakat bahwa dunia ini sebagai "jalan keselamatan” (bagi EP) dan "jalan beramal” (bagi MQ). Dapat dikatakan, Islam memberikan peranan yang signifikan dalam membangun the spirit of enterpreneurship bagi MQ.

${ }^{42}$ Gymnastiar, Etika ..., 11.

43Ibid., 11 
Dengan demikian, kenyataan ini membenarkan tesis Max Weber tentang fungsi agama sebagai pendorong utama dalam the spirit of enterpreneurship [of capitalism]. Kasus EP dan MQ sebagai bukti konkretnya

\section{Daftar Pustaka}

Abdullah Gymnastiar, Etika Bisnis MQ (Bandung: MQ Publishing, 2004). , Aa Gym Apa Adanya: Sebuah Qolbugrafi (Bandung: MQ Publishing, 1424/2002). , Demi Masa! Menggenggam Waktu, Meraih Keunggulan Diri (Bandung: MQS Publishing, 1425/2004). , Menuju Hidup Sukses: Kontribusi Spiritual-Intelektual Aa Gym dan Arifin Ilham (Semarang: Pustaka Rizki Putra, 2005).

Ajat Sudrajat, Etika Protestan dan Kapitalisme Barat: Relevansinya dengan Islam Indonesia (Jakarta: Bumi Aksana, 1994).

Anthony Giddens, Kapitalisme dan Teori Sosial Modern: Suatu Analisis Karya Tulis Marx, Durkheim dan Max Weber, ter. Suheba Kamadibrata (Jakarta: UI Press, 1985).

Bryan S. Turner, Sosiologi Islam: Suatu Tinjauan Analitis atas Tesa Sosiologi Weber, ter. G. A. Tocialu (Jakarta: Rajawali Press, 1984).

Hermawan Kartajaya, Aa Gym: A Spiritual Marketer (Bandung: MarkPlus \& Co-MQS Publishing, 2005).

Hernowo dan M. Deden Ridwan (ed.), Aa Gym dan Fenomena Daarut Taubiid (Bandung: Mizan, 2002).

Lester Kurtz, Gods in the Global Village: The World's Religions in Sociological Perspective (London: Pine Forge Press, 1995). , Tafsir Al-Qur'an Al-Karim: Tafsir atas Surat-surat Pendek Berdasarkan Urutan Turunnya Wabyu (Bandung: Pustaka Hidayah, 1418/1997). 
Max Weber, The Protestant Ethic and the Spirit of Capitalism translated by Talcott Parson (London: Routledge Classics, 2001).

Nanat Fatah Natsir, Etos Kerja Wirausahawan Muslim (Bandung: Gunung Djati Press, 1999).

Robert N. Bellah, Tokugawa Religion: The Values of Pre-Industrial Japan (USA: Macmillan Publisher Company, 1984).

Robert W. Green (ed.), Protestantism and Capitalism: The Weber Thesis and It's Critics (Boston: D. C. Heath and Company, 1959).

Sulaiman Al-Kumayi, Kearifan Spiritual: Dari Hamka ke Aa Gym (Semarang: Pustaka Rizki Putra, 2004).

W. Walter Rostow, "The Take of Self-Sustained Growth" dalam Agrawala dan Singh (ed.), The Economic of Under Development (New York: Oxford University Press, 1958). 